\title{
TRANSVERSALITY AND INTERDISCIPLINARY DISCUSSION IN POSTFOUNDATIONAL PRACTICAL THEOLOGY - REFLECTING ON JULIAN MÜLLER'S INTERDISCIPLINARY GUIDELINES
}

\author{
Author: \\ Zander van der Westhuizen

\section{Affiliation:} \\ ${ }^{1}$ Department of Practical \\ Theology, University of \\ Pretoria, South Africa
}

\section{Correspondence to:}

Zander van der Westhuizen

email:

zvdwesthuizen@gmail.com

\section{Postal address:}

Department of Practical

Theology, University of

Pretoria, Lynnwood Road,

Hatfield 0083, Pretoria,

South Africa

\section{Keywords:}

postfoundational;

Practical Theology;

interdisciplinary

discussion; mentorship;

narrative research;

methodology;

transversality

\section{Dates:}

Received: 23 Mar. 2009

Accepted: 19 July 2010

Published: 04 Nov. 2010

How to cite this article:

Van der Westhuizen,

Z., 2010, 'Transversality

and interdisciplinary

discussion in

postfoundational

practical theology -

reflecting on Julian

Müller's interdisciplinary

guidelines', HTS Teologiese

Studies/Theological Studies

66(2), Art. \#910, 5 pages.

DOI: 10.4102/hts.v66i2.910

This article is available at:

http://www.hts.org.za

(c) 2010. The Authors.

Licensee: OpenJournals

Publishing. This work

is licensed under the

Creative Commons

Attribution License.

\section{ABSTRACT}

This article reflected on Julian Müller's paper on the practical guidelines for conducting interdisciplinary work, a process which is similar to that which the author used during his own PhD studies on mentorship. Beginning this article by discussing postfoundationalism and transversal rationality, the author continued by describing his own process of interdisciplinary conversation, where various scholars participated in the interdisciplinary conversation on mentorship. An interview with a mentor and mentee was used as a local, real narrative in the process. In the final section, the author reflected upon his own process in relation to that of Müller and suggested a process with three movements for interdisciplinary work.

\section{INTRODUCTION}

I recently completed my thesis on the topic of mentorship in a local congregation. This study was done on the basis of a postfoundational epistemology and followed a narrative research approach in order to listen to the various narratives of eight co-researchers who formed part of a mentorship programme in a local congregation. The process of research was based on the seven movements developed by Julian Müller (2005):

- A specific context is described.

- In-context experiences are listened to and described.

- Interpretations of experiences are made, described and developed in collaboration with 'co-researchers'.

- A description of experiences as it is continually informed by traditions of interpretation.

- A reflection on the religious and spiritual aspects, especially on God's presence, as it is understood and experienced in a specific situation.

- A description of experience thickened through interdisciplinary investigation.

- The development of alternative interpretations that point beyond the local community.

(Müller 2005:8-9)

In this article, I focus on the movement of interdisciplinary investigation that formed part of my study in three ways. Firstly, I look at transversality as the basis of interdisciplinary discussion within this postfoundational approach. Secondly, I describe my own interdisciplinary process for the thesis. Finally, I reflect on Müller's process in his paper, 'Postfoundationalism as a practical way of interdisciplinary work: Narrative research on HIV and Aids' (2008). The aim of this article is thus to reflect on the practical guidelines of conducting an interdisciplinary investigation in practical theology.

\section{POSTFOUNDATIONALISM AND TRANSVERSALITY}

The Enlightenment gave birth to the epistemology 'foundationalism'

Foundationalism is the understanding that all our knowledge and beliefs are built on some basic foundation that is certain. These certainties hold the foundation for all the other knowledge and beliefs that are built upon them. Just as for a brick wall, the basis or foundation needs to be firm, then all the other bricks cemented on top of the foundation will be strong and stable as well.

The foundationalist's initial task, then, becomes that of establishing an epistemological foundation for the construction of the human knowing project by determining, and perhaps even demonstrating, the foundational beliefs or principles on which knowledge rests. Viewed under the foundationalist rubric, therefore, reasoning moves in only one direction - from the bottom up - that is, from basic beliefs or first principles to resultant conclusions (Grenz \& Franke 2001:30). Foundationalism also spilled over into the various sciences and theology. In theology there were debates on what to use as the foundation for theological reasoning and two distinct foundations emerged: human religious experience (liberalism) and the Bible (conservatists).

Today, however, foundationalism is in retreat. Within the postmodern epistemology the mere concept of foundations and certain knowledge is under constant critique. The ideal of certain basic knowledge in postmodernism is an impossible one and this has led to the search for a new epistemology and a new way of thinking beyond foundationalism.

Within the search for a nonfoundationalist approach there have been various thinkers who either based their thinking on coherence (where knowledge is related to other knowledge) or pragmatism. Some theologians have followed in the way of the nonfoundationalist philosophers, but the question would remain: in 'what sense, or to what extent, can the theological task incorporate a nonfoundationalist epistemology?' (Grenz \& Franke 2001:46). 
In the extreme form of nonfoundationalism there is a total relativism that does not allow any room for further conversation within this thinking. Van Huyssteen (1997) says that,

at the heart of this epistemological brand of nonfoundationalism we often find fideism: and uncritical, almost blind commitment to a basic set of beliefs. In this sense fideism can in some cases ironically turn out to be a foundationalism-in-disguise.

(Van Huyssteen 1997:3)

In the midst of this debate, Van Huyssteen proposes a 'third way': an approach that is beyond foundationalism, but not non-foundational. This approach is called postfoundationalism. According to Van Huyssteen (1997), postfoundationalism promotes two modes of thinking, in that it is contextual by nature, acknowledging the empirical and crucial role of interpreted experience, while simultaneously pointing beyond the local community towards an interdisciplinary conversation.

Unlike foundational notions of universality and ideas about general knowledge, a postfoundational approach listens to interpreted experience from a local situation. It values the local experiences about praxis, God and traditions, yet it does not confine itself to the local, but rather, promotes a move beyond the local into the public multidisciplinary realm. To do this, Van Huyssteen, Schrag and others speak about the development of a rationality that can be shared.

Van Huyssteen's (2000:428-429) article Postfoundationalism and interdisciplinarity: A response to Jerome Stone, further explains postfoundationalism and an interdisciplinary notion of rationality along the following lines:

- It acknowledges contextuality and the embeddedness of all our reflections in human culture.

- It is serious about interpreted experience or experiential understanding and the way that tradition shapes this.

- It opens the possibility to explore freely the patterns that might be consonant with the biblical paradigm.

- It can be seen as a skill that enables us to gather and bind together patterns of our interpreted experience.

The concept of transversality thus replaces the modern understanding of universality and rationality.

Owing to the emphasis on interdisciplinarity and the dialogue between various disciplines in a postfoundational approach, time has to be spent on the understanding of rationality, that is, the basis on which interdisciplinary conversation is made possible.

Interdisciplinary discourse, then, is the attempt to bring together disciplines or reasoning strategies that may have widely different points of reference, different epistemological foci, and different experiential resources.

(Van Huyssteen 2006:9)

Transversality has become known through the thoughts of various other disciplines. In mathematics, for instance, the concept of transversality is described as 'enabling a line to intersect two or more lines or surfaces without achieving coincidence' (Schrag 1992:148). In the other sciences, similar metaphors are used to describe the idea that there are ways in which various disciplines (that seem unable to share in conversation) can coincide from their various perspectives.

The use of the concept/metaphor of transversality in all of these approaches exhibits interrelated senses of lying across, extending over, intersecting, meeting and converging without achieving coincidence. By way of complex manoeuvres of borrowing and conjugation, metaphorical play and refiguration, the various disciplines make use of these interrelated senses ensconced within transversality (Schrag 1992:149).

Van Huyssteen also uses the concept of transversality to reveal the possibility of a shared rationality. Müller (2008) argues that although Van Huysteen does not specifically use the term 'social constructionism', the postfoundational approach places itself within the same epistemology. The interdisciplinary conversation made possible by transversal rationality implies the social construction of knowledge. In the epilogue of his article, Müller (2008) argues that in an interdisciplinary investigation, postfoundational epistemology must be used with social constructionism and hermeneutics. I will reflect further on this in a later section.

The key to transversality and the equilibrium between science and theology is the shared rationality between us all. The way we conduct conversations and engage in mutual interpretations we, as practical theologians, are able to participate on a democratic basis in the conversation about mentorship. Transversality, therefore, justifies and urges an acknowledgement of multiple patterns of interpretation as one moves across the borders and boundaries of different disciplines (Van Huyssteen 2000:430).

Transversality provides us with different ways to look at issues or disciplines that are legitimate and is a process that has integrity. It is due to this understanding of shared rationality that a discipline such as theology can be public and contribute meaningfully to the interdisciplinary discussion.

\section{MY OWN INTERDISCIPLINARY PROCESS ON MENTORSHIP}

Mentorship is a theme that involves a number of other disciplines. I decided that the best way to integrate interdisciplinary contributions to my research process was not only to examine the literature, but also to have a conversation about mentorship with scholars from other disciplines. For this conversation I invited the following scholars from different fields:

- Dr H. Steyn - Life coaching, mentorship in the business context

- Prof. H. de Beer - Human Resource Management/Industrial Psychology

- Dr C. Human - Psychology

- Mrs P. Barnard - Social Work

- Prof. J.C. Müller - Practical Theology

While my research was underway, Müller (2008) developed the four questions for his own interdisciplinary process and I decided to make use of these questions in my process, as I believed my process could help to evaluate these questions and contribute to the development of ways to conduct interdisciplinary conversations in the future. The four questions formulated by Müller (2008) read:

- When reading the narrative, what are your concerns?

- What do you think is your discipline's unique perspective on this narrative?

- Why do you think your perspective will be understood and appreciated by people from other disciplines?

- What would your major concern be if the perspective of your discipline might not be taken seriously?

(Müller 2008:n.p.)

Müller's process, however, was different to mine. In his process he used a narrated story of a boy named, Sizwe who was afraid of being tested for HIV. He sent this story to the scholars along with the four questions. These scholars were asked to respond in writing and their verbatim responses were included in Müller's article, along with Müller's reflection on them.

For my process, I arranged a sit-down discussion with all the scholars I mentioned above. Prior to this discussion, I sent a narrative (in interview form) of two of my co-researchers, a brother and sister, to each participant together with the four questions. They had time before the discussion to read through the interview and think about the questions and during the sitdown discussion we worked through the questions and had a constructive discussion on mentorship. 
BOX 1

Notes on the discussion: When reassign the narrative, what are your concerns?

Human:

- What is the definition of mentorship?

- Is there structure to it?

- I am concerned about anxiety in terms of the struggle with roles in the story.

Does the mentor have experience?

The mentor must have more knowledge than the mentee.

Are they free within the mentorship, or is it the way system still has the power to mentor?

De Beer:

- Here needs to be structure to facilitate change.

What is the overall aim?

Are there any measurable outcomes?

The focus should be growth.

Steyn:

- The brother's anxiety is a concern to me.

- The advice given concerns me.

Where is the wisdom?

- There should be a 'divorce clause' if the relationship does not work out.

Barnard:

- What is the definition of mentorship?

- The age difference between the mentor and mentee is too small.

- The rolls that overlap are not clear.

Müller:

Do we engage in mentorship for an organisation, or mentorship for the sake of mentorship?

There are different views about mentorship.

- Everybody is concerned about the brother in the story.

General themes from conversation

-What is a common definition?

- Respect is important in a mentorship relationship.

Wisdom and life experience is needed to be a mentor.

Critical questions can be asked in the relationship.

Knowledge is about integration.

Competence needed by a mentor: knowledge, abilities, values and attitude.

I decided not to include the narrative of the brother and sister in this article for two reasons. Firstly, it is lengthy and, secondly, the aim of this paper is to evaluate the process and not the specific content. However, I do reflect here on the discussion's content itself.

Unlike Müller's paper, it was not possible to write down the specific responses of each participant; instead, I made process notes on the various topics that arose. During the discussion it also became clear that the group 'jumped' between the questions. They would discuss issues wider than the specific question asked, or referred back to a previous question or repeated themselves. Box 1 depicts an example of my process notes on the first question.

I decided to summarise the discussion and send it to the scholars, asking them if they would like to provide input on my summary. The summary highlighted that there were a few aspects on

\section{BOX 2}

Mutual agreement

- From the viewpoint of all the disciplines, everyone was concerned about the brother as the mentor in this particular narrative. They were concerned about his struggle in defining his various roles in the relationship.

All the disciplines felt strongly about the relationship as the central focal point in mentorship.

Growth is the basic aim of mentorship.

- There should be a very clear definition about mentorship and how it is understood.

understood.

The aims of the programme should be clear.

Most of the disciplines emphasised knowledge, abilities, life experience and wisdom as prerequisites in becoming a mentor.

Expectations should be clear in terms of aims and definitions in the programme. The gap in expectations creates anxiety and tension.

\section{BOX 3}

\section{Differences}

Notions about the aim of the programme and mentorship in general differed between the various disciplines.

The context of this particular programme, and that of most of the disciplines, The context of this partic
differed substantially.

differed substantially.

The definition of mentorship also differed across the disciplines. In the business world the definition of mentorship can be totally different from that in the church context.

The way mentorship is approached in each discipline also seemed to differ. which all of the disciplines agreed, as well as aspects on which they disagreed, or approached differently. These similarities and differences are reflected in Box 2 and Box 3, respectively.

By positioning oneself as postfoundational, the resultant emphasis on interdisciplinary conversation is one of the major contributions to this process. After becoming aware of the confines of any discipline, it now almost seems unethical not to engage in some form of dialogue with other disciplines. To my mind, this also entails more than just consulting the literature; the experience of being in physical conversation together, with the same narrative or concrete praxis as basis, is much more rewarding. Conversation is a dynamic process that, in this case, made a valuable contribution to the research.

The insight from the conversation helped my process by posing new questions from different perspectives. The questions that were asked during the conversation might come from a different context but it helps to reveal a process of deconstruction in my research and to explore alternative understanding.

It is, however, a challenging conversation. During the conversation and in my reflection I became aware that there were various differences in terms of epistemology between the different scholars. To me this was apparent even though it was not discussed, which made for a challenging environment to 'stand your ground' without taking a position against the various perspectives offered. The process of interdisciplinary discussion also proves the lack of universality as seen in Müller's (2008) paper, in that there is not one universal agreement on knowledge, but a number of contributions to the conversation. However, this does not mean that the various disciplines have so little in common that conversation is not possible, but simply that how this conversation is conducted and integrated seems to be the biggest challenge.

There was a concern about the mentor in the narrative. This was a significant perspective and agreed with the fact that there was also concern mentioned for Sizwe in Müller's (2008) paper.

Critical questions that were raised in the conversation with regards to the context of the church as institution include, (1) Is the aim of the programme to 'mentor' young people into the power relations and formalised ideas of the institution?, (2) How is it understood?, and (3) Is theology offended by such questions? This was, to my mind, a valuable contribution to the conversation, because it helps to maintain a critical reflection on one's own discipline to see how it is incorporated into the practical work of the church. It reminds one of the work of Foucault and Derrida.

The discussion was a first in my own research history and proved to be a vital contributor to the research that was conducted for my thesis.

\section{A REFLECTION ON MÜLLER, MY OWN PROCESS AND INTERDISCIPLINARY CONVERSATION AS PART OF PRACTICAL THEOLOGICAL RESEARCH}

To assist me in my reflection on the processes and interdisciplinary conversation in general, I decided to formulate a few questions as follows:

- Are the questions the right questions?

- Is there a difference between open discussion and written discussion?

- Who is marginalised in the discussion?

- Would the conversation be different without the voice of Practical Theology?

- What are we missing?

In this section, I reflect on these questions in order to assess how useful they were in assisting me to formulate an interdisciplinary process of mentorship. 


\section{The practical guidelines of the process}

The process I followed led me to make many of the same conclusions as Müller (2008):

- A local, contextual narrative about the mentorship relationship between a brother and a sister was used. This enabled the conversation to be embedded in a real-life story and, as such, helped the process of discussing the various disciplines' perspectives. Although the conversation was rooted in the story, a more general discussion about mentorship arose. This was different to the process of Müller, where each person gave his or her response in writing.

- The common concern, as with Müller, was the person in the story. In Müller's story it was Sizwe. In my process it was the brother as the mentor. The transversal platform for understanding was also apparent in this process.

- There were differences and similarities:

- There was enough 'common ground' between the various disciplines for a conversation to take place and this was facilitated by the questions asked.

- There was no universal perspective or truth about the brother's and sister's mentoring relationship. It was apparent in this process that the various disciplines were indifferent in their approach to mentorship in general.

The first and most apparent difference between my process and that of Müller (2008) is the way in which the responses were gathered. In Müller's process, each participant wrote his or her own responses to the questions without being in physical conversation with the other disciplines. These responses were quoted and respondents could comment on Müller's reflections on them. In my approach, however, respondents could read through the interview, think about it without formulating responses on paper and then join in the physical conversation.

Müller aimed at looking at transversal rationality as a process and thus reflected on that, whereas my aim was wider. I wanted to facilitate an interdisciplinary conversation that formed part of the larger research process on mentorship. I asked myself what would have been different if the participants had the opportunity in my process to only formulate their responses on paper. The conversation made it more difficult to document actual responses and keep them specific to a participant. On the other hand, the conversation was truly a conversation - there was interaction between the participants and, as such, between the various disciplines. Different questions could be asked and Müller's four questions only formed the basis of the conversation. The differences in the participants' answers and contributions were more apparent and yet both processes established most of the same conclusions on transversal rationality.

Concerns can be raised about the questions formulated by Müller. Are they the right questions? Should they be formulated differently? I would argue that the questions are open enough to facilitate the process that Müller aimed for. They are also efficient enough to start the process I aimed for. There is, however, more value to a physical discussion that reveals the possibility for new questions to be formulated by the group of participants. To further to conversation, one could formulate a question such as: What question would your discipline like to ask in an interdisciplinary conversation such as this one? Indeed, I would suggest adding this question to the process, for future studies. I would also argue that combining the two methods used (i.e. my own and that of Müller) would be a valuable contribution to an interdisciplinary process. As such, I propose an interdisciplinary process with three movements:

- Participants read through a local contextual story and respond to the four questions set out by Müller, as well the question I proposed in the previous paragraph. These written responses are sent back to the facilitator and distributed to all participants.
- One or more physical conversations are held to discuss the responses and formulate new questions about the specific story. If this movement is not possible due to participants being unable to attend a physical conversation, other forms of electronic conversation can be considered.

- The facilitator compiles a final summary and a reflection on the discussion and this is distributed to all participants, who, in turn, make a final round of reflection and additions to this reflection before the process is concluded.

\section{The marginalised in the process}

In Müller's (2008:n.p.) epilogue, he reflects on the so-called 'dangerous question'. A similarly important reflective question for me would be: Who is marginalised in this conversation? During my process, I felt that some of the concerns raised about the brother in my story would have been answered if the participants knew the brother better and could listen to more of his story. If the brother could participate in the conversation he would probably disagree with some of the comments or understandings of the interdisciplinary group. The same would be true of the sister as the mentee in the interview.

I would agree with Müller (2008:n.p.) that marginalization is an important concern.

- Why was the question not raised of what the brother and sister's concerns would be?

- Why did we feel that their voice was present in their story without thinking about involving them in the process?

The question would remain on how the siblings should be heard and involved in this process. If they were physically present for the conversation it could be a hindrance or barrier to the conversation, as the participants might then not raise their concerns honestly for fear of offending the brother or sister. The siblings might also have felt uncomfortable in this type of conversation with unknown professional academics.

Thus we are confronted with a paradox. On the one hand, we agree that their voice should be part of the process. On the other, the question is raised:

- Why would they have any reason to feel uncomfortable in the process?

- Ethically speaking, should there be any reason why such a conversation could not take place in their presence?

A way should be found in each process to add the voices within the stories to this conversation in a safe and comfortable way. They could, for instance, be asked to take part in the third movement of my proposed process to give input before the final conclusion. More than one conversation could also be considered, where they could participate in a later conversation and reflect on the group's discussions.

This proposal is important and should be addressed in the process. There might be others who are also marginalised in the process: other disciplines not represented, scholars within certain disciplines that would vary in opinion, other participants in the study or a particular story. For this reason Müller (2008) argues that social constructionism and hermeneutics must help us to be sensitive to other voices and I would add deconstruction, specifically. This emphasis will help to frame the question of marginalisation and power relations in the research process.

\section{The contribution of Practical Theology to an interdisciplinary conversation}

During the process I felt compelled to reflect on the contribution of practical theology in the conversation and, as such, I asked:

- Would the conversation be different without the voice of Practical Theology?

- What is the unique contribution we as Practical Theologians are making towards an interdisciplinary conversation based on a transversal rationality? 
The process taught me that before a discipline can participate in a conversational process with other disciplines it should be understandable on it's own biases, position and concerns. This level of self-awareness helps the conversational process.

Browning (1991:38-42) does not provide a specific definition of practical theology, but in his writings on understanding and practical wisdom he argues that we cannot work with only the Barthian understanding that the theory is just applied to the practice. The hermeneutics of practical wisdom and thinking (and thus practical theology) imply that we move from practice to theory to practice (Gadamer's theology). This simply means that in practical theology we are in a constant conversation with the narratives of the Christian faith community and the practical situations in everyday life. We try to understand and bring meaning into the context of our present situation, without forgetting the past narratives, and by creating future narratives.

Elaine Graham (2000:104-117) also writes about practical wisdom and comes to the conclusion that practical theology should be a transforming practice. She writes:

A vision of God embedded in human encounter and renewal animates genuinely disclosive practical wisdom: words made flesh in a community which fosters a generosity to others. Such transformative practice facilitates and encourages the exercise of the qualities of solidarity, wholeness and reconciliation, practices by which divine disclosure can be effected.

(Graham 2000:112)

Gerkin (1991:13), writing in the context of pastoral care for individuals and groups concerning addressing the fluid norms and boundaries in society, makes the paradigm shift that practical theology is not only aimed at the ministry practice of the church, but also at the presence of the church in society. This idea is furthered developed into the idea that theology is public and needs to be an interdisciplinary conversational partner.

Alastair Campbell (2000:84) also makes a few conclusive points as to the nature of practical theology that I find satisfactory. In summary, he mentions five important aspects:

- Practical theology is concerned with the study of specific social structures and individual initiatives within which God's continuing work of renewal and restitution becomes manifest. These may be found either inside or outside the life of the church.

- Practical theology can no longer take the functions of the ordained ministry as normative for its divisions of subject matter and delineation of scope.

- The relationship between practical theology and other theological disciplines is neither inductive, nor deductive. The relationship is to be seen as a 'lateral' rather than a 'linear' one.

- Because of the 'situation-based' method it employs, practical theology can be expected to be fragmentary and poorly systemised.

- The findings of practical theology can be expected to be mostly in the form of concrete proposals.

Based on this understanding of practical theology, I would argue that those of us who work within this discipline contribute to the interdisciplinary conversation on a number of levels. We help other disciplines to be concerned with the local, the contextual and the concrete narratives of our time. We are not unique in this, for there are other disciplines that also focus on local narratives, but the importance of this strategy seems to be underestimated in some disciplines and thus we can contribute by bringing this perspective to the conversation.

On another level as practical theologians, we contribute by focusing and raising concern for the transformative process when listening to people's stories. We listen for the transformative nature of God's work and how this is present in stories. We are generally concerned about spirituality and systems of religion and, as such, we would want to listen to how these are integrated into people's stories and how God is experienced in a particular situation. Practical theologians can also contribute to interdisciplinary conversation by voicing the narratives of the greater Christian community and investigating how these traditions of interpretations have influenced a particular narrative.

\section{CONCLUSION}

\section{What are we missing?}

The process of interdisciplinary conversation helped me to grow in my understanding of the value of interdisciplinary work. We can easily be comfortable in our own disciplines, especially if we work within a foundational paradigm and there is no concern to interact with other disciplines due to our epistemology. Yet, if we are honest about our need and the nature of knowledge, we would rather conclude that a transversal rationality can exist between disciplines and interdisciplinary work is crucial in the understanding and acquiring of knowledge. We should thus be asking: What are we missing when we work within our discipline's own constraints?

Within the practical guidelines and process of doing interdisciplinary work it is clear that this is a challenging environment. The process of this article, as well as that of Müller (2008) provides the first step on the journey to discovering the value of interdisciplinary work as practical theologians. This is a difficult task that needs to be developed further and so, in this process we should reflect and ask: What are we missing in this process? In this way, we can work with subjective integrity, in search of common understanding and new insight.

\section{REFERENCES}

Browning, D.S., 1991, A fundamental practical theology, Fortress Press, Minneapolis, MN.

Campbell, A., 2000, 'The nature of practical theology', in J. Woodward \& S. Pattison (eds.), The Blackwell reader in pastoral and practical theology, pp. 77-88, Blackwell, Malden, MA.

Gerkin, C.V., 1991, Prophetic pastoral practice, Abingdon Press, Nashville, TN.

Graham, E., 2000, 'Practical theology as transforming practice', in J. Woodward \& S. Pattison (eds.), The Blackwell reader in pastoral and practical theology, pp. 104-117, Blackwell, Malden, MA.

Grenz, S.J. \& Franke, J.R., 2001, Beyond foundationalism: Shaping theology in a postmodern context, Westminster John Knox Press, Louisville, KY.

Müller, J.C., 2005, 'A postfoundationalist, HIV-positive practical theology', paper presented at the International Biennial Conference of the International Academy of Practical Theology, Brisbane, Australia, 25-29 June.

Müller, J.C., 2008, 'Postfoundationalism as a practical way of interdisciplinary dialogue: narrative research on HIV and Aids', paper delivered at 3rd International Conference on Interdisciplinary Social Sciences, Prato, Italy, 22-25 July.

Schrag, C.O., 1992, The resources of rationality: A response to the postmodern challenge, Indiana University Press, Bloomington, IN.

Van der Westhuizen, Z., 2008, 'Mentorship narratives in a local congregation: A postfoundational practical theological study', PhD thesis, Department of Practical Theology, University of Pretoria.

Van Huyssteen, J.W., 1997, Essays in postfoundationalist theology, Eerdmans, Grand Rapids, MI.

Van Huyssteen, J.W., 2000, 'Postfoundationalism and interdisciplinarity: A response to Jerome Stone', Zygon: Journal of Religion and Science 35(2), 427-439.

Van Huyssteen, J.W., 2006, Alone in the world? Human uniqueness in science and theology, Eerdmans, Grand Rapids, MI. 